\title{
Second Thoughts
}

\section{EPIDEMIOLOGISTS AND PUBLIC HEALTH POLICY}

\author{
BETSY FOXMAN \\ Department of Epidemiology, University of Michigan, School of Public Health, \\ Ann Arbor, MI 48109, U.S.A.
}

(Received in retised form 7 March 1989)

\begin{abstract}
"All scientific work is incomplete - whether it be observational or experimental. All scientific work is liable to be upset or modified by advancing knowledge. That does not confer upon us a freedom to ignore the knowledge we already have, or to postpone the action that it appears to demand at a given time."
\end{abstract}

AUSTIN BRADFORD HiLl [1]

Epidemiologists have a long history of influencing and setting policy designed to improve the public's health. From John Snow's studies of cholera leading him to remove the Broad Street pump, to the Centers for Disease Control (CDC) guidelines for preventing HIV transmission in the workplace [2], epidemiology has historically served as a basis for public health policy. Results from epidemiologic studies are used by the medical community to set or evaluate treatments, by hospitals to change or evaluate procedure, and by industry to evaluate and market products. Interpretation of a legal issue may rest on the results of epidemiologic studies. Epidemiologic data also influence public policy, from setting environmental standards to establishing a center on accidents and injuries.

Despite this history, epidemiologists have been slow to accept their roles as advisors and influencers of policy makers. These roles appear to conflict with the self-image of the scientist, and to raise ethical questions. Indeed, some epidemiologists believe the profession simply should not be involved in policy making [3]. Thus, while epidemiologists are clearly the most qualified to interpret epidemiologic studies used to set public health policy, epidemiologists have no organization which speaks to policy making bodies. I propose that the profession should have such an organization, which I shall call the "Epidemiologic Policy Forum". In this article I illustrate how such an organization might influence public health policy.

The argument against scientific involvement in policy making rests on two points. First, that the role of data in policy may be minimal after balancing the special interest and divergent values of the political process; and second, that the objective of science is to further knowledge, not make policy [3]. While I would not argue with either of these points, there are public health decisions which are based directly upon available epidemiologic data. In such cases, the epidemiologist is best suited to evaluate these data, and the existence of an Epidemiologic Policy Forum might lead to a more rapid change in public beliefs and in the setting of policy.

An example of where an Epidemiologic Policy Forum might have made a difference can be seen when reviewing the history of aspirin warning labels against Reye's syndrome. Reye's syndrome, a serious and often fatal disease which occurs most frequently among children whose viral illness is treated with aspirin [4], was first described in 1963 [5]. An association between Reye's syndrome and aspirin was suggested by Giles in 1965 [6]. By 1976, there was sufficient evidence for the Food and Drug 
Administration (FDA) to recommend against the use of antiemetics, aspirin and acetaminophen in children [7]. In 1980, CDC, on the basis of three case-control studies it conducted with state health departments, recommended caution in using aspirin to treat children with viral illnesses, particularly chickenpox and influenzalike illnesses [8]. A consensus development conference held in March 1981 made a similar recommendation [9]; by February, 1982 CDC had strengthened the recommendation from caution to an advisement that aspirin use increased risk of Reye's syndrome [10]. This caution was echoed by the American Academy of Pediatrics [11]. However, government action was not taken until 1985 when a voluntary and subsequently mandatory warning label program was instituted [12].

The presence of an Epidemiologic Policy Forum might have led to a more rapid adoption of warning labels. As early as 1980, CDC was advising caution in treating children with viral illnesses [8]. A statement from an Epidemiologic Policy Forum at the same time might have heightened public awareness. In 1982, the Academy of Pediatrics still felt that labeling aspirin-containing preparations as contraindicated in the treatment of influenza or chicken pox should be delayed; or only the 'flu indication on aspirin should be deleted [13]. An active Epidemiologic Policy Forum might have been able to sway the FDA toward labeling in 1982 when first proposed, rather than 1986 when labeling was finally implemented.

In addition, an Epidemiologic Policy Forum may have evaluated the effectiveness of the public education program. Studies in Tecumseh, Michigan showed that parents were already substituting acetaminophen for aspirin in the early Eighties [14]. If public education were effective, removing the 'flu indication from aspirin labels might have been a sufficient intervention.

Having an Epidemiologic Policy Forum would serve to educate both the public and medical community to the problems of interpretation of epidemiologic studies. The controversy and subsequent withdrawal of the antinauseant, Bendectin, from the market illustrates how difficult it is to show an absence of association with epidemiologic methods, and the public's misunderstanding of this difficulty. Bendectin was first brought to the public's attention via a National Enquirer article reporting the results of a case-control study [15]. The study showed a statistically significant association for Bendectin use and congenital cardiac malformations. Almost all subsequent studies using either a cohort or case-control design found no association with congenital malformations and Bendectin [16]. However, because of financial concerns resulting from numerous lawsuits, and the increasing cost of insurance premiums, the manufacturer ceased production of Bendectin. Thus, despite the lack of epidemiologic evidence to support an association between Bendectin and congenital malformations, the controversy and subsequent litigation were sufficient to remove a well understood and apparently effective drug from the market. A statement from the Epidemiologic Policy Forum, which would undoubtedly be carried in most newspapers (as are the pronouncements of the American Academy of Pediatrics, for example), might have served to change public opinion sufficiently to avoid the total removal of the drug. Removal of Bendectin from the market left the physician completely on his own with respect to prescribing for morning sickness during pregnancy, and subject to the same litigation which the drug companies were trying to avoid.

The limitations of epidemiologic studies are well known to the epidemiologic community $[17,18]$, although there is far from universal agrcement as to the appropriate remedies. These limitations should be balanced against the needs of the policy maker who frequently must respond to an anxious and demanding public. Although the epidemiologic community understands that newsworthy hypothesis-generating studies, leading to intriguing hypotheses such as coffee drinking causes pancreatic cancer [17], are not designed to test hypotheses but merely suggest areas for future research, this distinction may be invisible to the public and policy-maker alike. One would hope that an Epidemiologic Policy Forum would counsel patience when warranted, as well as intervention, when appropriate. Without better understanding of possible alternative explanations for observed relationship(s), and suitable confirmation from hypothesis-testing studies, the results of hypothesis-generating studies generally should not be used for decision making. Policy makers should always consider that the null hypothesis (of no association) might be true, or that the factor of interest is merely a strong correlate of the true causal factor, lessons the Epidemiologic Policy Forum could reinforce. 
Epidemiologists are most qualified to evaluate the validity of epidemiologic studies. Although the validity of a scientific theory cannot be decided by committee, I would choose the opinion of a group of epidemiologists who have a good understanding of the strengths and weaknesses of various research methods over the opinion of authorities lacking such training. Policy makers are forced to make decisions based upon their own opinions and those of qualified experts. When epidemiologists avoid helping policy makers formulate public health policy, others less qualified must do so in their stead. Epidemiologists should consider establishing a forum for deciding and publicizing the profession's opinions regarding issues of public health importance.

Acknowledgements - The author would like to thank Miche Ibrahim, James Koopman, William Satariano, Lowell Sever, and MaryFran Sowers for helpful comments on an earlier version of this manuscript.

\section{REFERENCES}

1. Hill AB. The environment and disease: association or causation? Proc R Soc Med 1965; 58: 295-300.

2. Centers for Disease Control. Summary: recommendations for preventing transmission of infection with human T-lymphotropic virus type II/lymphadenopathy-associated virus in the workplace. MMWR 1985; 34: 681.

3. Rothman KJ, Poole C. Science and policy making. Am J Public Health 1985; 75: 340-341.

4. Pinsky PF, Hurwitz ES, Schonberger LB, Gunn WJ. Reye's syndrome and aspirin: evidence for a dose- response effect. JAMA 1988; 260: 657-661.

5. Reye RDK, Morgan G, Baral J. Encephalopathy and fatty degeneration of the viscera: a disease entity in childhood. Lancet 1963; 2: 749-752.

6. Giles HM. Encephalopathy and fatty degeneration of the viscera. Lancet $1965 ; 1: 1075$.

7. Food and Drug Administration. Reye's Syndrome: etiology uncertain but avoid antiemetics in children. FDA Drug Bull 1976; 6: 40-41.

8. Centers for Disease Control. Reye Syndrome-Ohio, Michigan. MMWR 1980; 29: 532-539.

9. National Institutes of Health. The diagnosis and treatment of Reye's syndrome. JAMA 1981; 246: 2441-2444.

10. Centers for Disease Control. National surveillance for Reye Syndrome, 1981: update, Reye syndrome and salicylate usage. MMWR 1982; 31: 53-60.

11. Committee on Infectious Diseases. Aspirin and Reye Syndrome. Pediatrics 1982; 69: 811-812.

12. Food and Drug Administration. Proposed labeling for oral aspirin-containing drug products. Federal Register 1985; 50: $51400-51404$.

13. American Academy of Pediatrics. Statement dated 19 November 1982.

14. Remington PL, Rowley D, McGee H, Hall WN, Monto AS. Decreasing trends in Reye Syndrome and aspirin use in Michigan, 1979 to 1984. Pediatrics 1986; 77: 93-98.

15. Rothman KJ, Fyler DC, Goldblatt A, Kreidberg MB. Exogenous hormones and other drug exposures of children with congenital heart disease. Am J Epidemiol 1979; 109: 433-439.

16. Sheffield LG, Batagol R. The creation of therapeutic orphans-or, what have we learnt from the Debendox fiasco?, 1985. Med J Aust 1985; 143: 143-147.

17. Feinstein AR. Scientific standards in epidemiologic studies of the menace of daily life. Science 1988; 242 : 1257-1263.

18. Vandenbroucke JP, Pardoel VPAM. An autopsy of epidemiologic methods: the case of "poppers" in the early epidemic of the acquired immunodeficiency syndrome. Am J Epidemiol 1989, 129: 455-457. 